\title{
Interactions of the Trypanosoma brucei brucei zinc-finger-domain protein $\mathrm{ZC} 3 \mathrm{H} 28$
}

Tania Bishola and Christine Clayton.

Heidelberg University Centre for Molecular Biology (ZMBH), Im Neuenheimer Feld 282, D69120 Heidelberg, Germany

*to whom correspondence should be addressed. e-mail cclayton@zmbh.uni-heidelberg.de, tel +496221546876

\section{Abstract}

In Trypanosoma brucei and related Kinetoplastids, regulation of gene expression occurs mostly post-transcriptionally, and RNA-binding proteins play a critical role in the regulation of mRNA and protein abundance. Trypanosoma brucei ZC3H28 is a $114 \mathrm{KDa}$ cytoplasmic mRNA-binding protein with a single $\mathrm{C}(\mathrm{x})_{7} \mathrm{C}(\mathrm{x})_{5} \mathrm{C}(\mathrm{x})_{\mathrm{s}} \mathrm{H}$ zinc finger at the $\mathrm{C}$-terminus and numerous proline-, histine- or glutamine-rich regions. We here show that $\mathrm{N}$-terminally tagged $\mathrm{ZC} 3 \mathrm{H} 28$ copurifies ribosomes, various RNA-binding proteins, and the translation initiation complex EIF4E4/EIF4G3. ZC3H28 is preferentially associated with long RNAs that have low complexity sequences in their $3^{\prime}$-untranslated regions. When tethered to a reporter mRNA, $\mathrm{ZC} 3 \mathrm{H} 28$ increased the mRNA level without a corresponding increase in protein expression; this suggests that it stabilized the reporter but at the same time suppressed its translation. Indeed, there was a clear negative correlation between $\mathrm{ZC} 3 \mathrm{H} 28$ mRNA binding and ribosome density. After $\mathrm{ZC} 3 \mathrm{H} 28$ depletion, the relative levels of ribosomal protein mRNAs increased while levels of some long mRNAs decreased, but there is no overall correlation between binding and RNAi effects on mRNA abundance. We speculate that $\mathrm{ZC} 3 \mathrm{H} 28$ might be implicated in stabilizing poorly-translated mRNAs. 


\section{Introduction}

Trypanosoma brucei and related kinetoplastid parasites rely heavily on post-transcriptional mechanisms for control of gene expression. Control is required not just to determine steadystate expression, but also to respond to external stresses and to adapt to different environments in infected mammals and in the definitive host, the Tsetse fly. Most transcription is polycistronic: mRNA levels are determined by gene copy numbers, the efficiency of mRNA processing (via trans splicing and polyadenylation) and the rate of mRNA decay, and rates of protein synthesis also vary considerably. RNA-binding proteins are critical at all stages (Clayton, 2019).

In this paper we studied the role and interactions of ZC3H28 (Tb927.9.9450), a $114 \mathrm{KDa}$ (1030-residue) protein with a single $\mathrm{C}(\mathrm{x})_{7} \mathrm{C}(\mathrm{x})_{5} \mathrm{C}(\mathrm{x})_{\mathrm{s}} \mathrm{H}(\mathrm{CCCH})$ zinc finger at the C-terminus. The central part of the protein has multiple proline-, histidine- or glutamine-rich regions, including $(\mathrm{H})_{11},(\mathrm{H})_{17},(\mathrm{Q})_{11}$ and $(\mathrm{H})_{14}$ with a single interruption (Figure 1A). Unsurprisingly, Phyre2 predicts that about $70 \%$ of the protein lacks ordered secondary structure. ZC3H28 expression is not developmentally regulated. Results from a high-throughput RNAi screen indicated that $\mathrm{ZC} 3 \mathrm{H} 28$ is essential in bloodstream forms, and during differentiation to, and early survival as, the procylic form (Alsford et al., 2011). High-throughput tagging localised it to the cytoplasm (Dean et al., 2016). It can also be cross-linked directly to mRNA (Lueong et al., 2016). In the "tethering" assay, we express in trypanosomes the protein of interest fused to the lambdaN peptide together with a reporter mRNA with "boxB" sequences that are bound with high affinity by the lambdaN peptide. In a high-throughput screen, $\mathrm{ZC} 3 \mathrm{H} 28$ activated reporter expression (Erben et al., 2014), suggesting that it either increases translation efficiency, or stabilises the mRNA, or both. A study of proteins associated with the two poly $(A)$ binding proteins showed that $\mathrm{ZC} 3 \mathrm{H} 28$ was preferentially associated with PABP2 (Zoltner et al., 2018). ZC3H28 also copurified with the mRNA encoding variant surface glycoprotein (VSG), but not the mRNA encoding alpha tubulin (Melo do Nascimento et al., 2021)

One known mechanism for post-transcriptional activation in trypanosomes is recruitment of a complex containing MKT1, PBP1 (poly(A)-binding-protein-binding-protein), XAC1 (expression activator 1), LSM12 and the poly(A) binding protein PABP2 (Nascimento et al., 2020; Singh et al., 2014). The activation is likely to be a consequence of PABP2 binding and perhaps also recruitment of the translation initiation complex EIF4E6/EIF4G5. ZC3H28 was strongly and significantly enriched after affinity purification of XAC1 (Nascimento et al., 2020), but was barely detectable in a purified MKT1 preparation (Singh et al., 2014). ZC3H28 lacks a known $H(N / D) P Y$ consensus motif (Singh et al., 2014) for MKT1 interaction. However several proteins that enrich with MKT1 have polyglutamine tracts instead (Singh et al., 2014).

In this work we investigated the interactions of $\mathrm{ZC} 3 \mathrm{H} 28$ with mRNAs and proteins, and the effects of $\mathrm{ZC} 3 \mathrm{H} 28$ depletion on the transcriptome.

\section{Results}

\section{$\mathrm{ZC} 3 \mathrm{H} 28$ is present in kinetoplastids and a bodonid.}

Examination of representative Kinetoplastid genomes revealed $\mathrm{ZC} 3 \mathrm{H} 28$ in all of them. The position in the genome upstream of the gene encoding peroxisomal protein PEX13 is also conserved although the synteny is not annotated. We also found a homologue in the bodonid Bodo saltans, but not in Euglena gracilis. All of the sequences examined (except the Leptomonas seymouri sequence, which has a frame-shift near the C-terminus) have the Cterminal zinc finger and various histidine- and glutamine-rich regions (Supplementary Figure S1).

\section{$\mathrm{ZC} 3 \mathrm{H} 28$ is an essential protein}

Results obtained in high-throughput screens are not always reliable, so we first confirmed that lambdaN-ZC3H28 indeed activates expression of a boxB-containing chloramphenicol acetyltransferase (CAT) - encoding mRNA. Results for four independent clones confirmed 
roughly 2-fold increases in CAT protein but 4-6-fold increases in the amount of mRNA (Figure $1 \mathrm{~B}, \mathrm{C})$. These results suggest that $\mathrm{ZC} 3 \mathrm{H} 28$ might increase mRNA stability while suppressing translation.

Next we assessed the effects of $\mathrm{ZC} 3 \mathrm{H} 28$ depletion on the proliferation of bloodstream-form trypanosomes. We first integrated a plasmid for inducible RNAi in EATRO1125 cells, which are competent for differentiation into the procyclic (tsetse midgut) form. ZC3H28 RNAi only somewhat inhibited cell proliferation. We therefore instead used a cell line that we had generated for affinity purification of $\mathrm{ZC} 3 \mathrm{H} 28$. This line was made with Lister 427 bloodstream forms, which grow to higher densities but are unable to complete differentiation. We integrated a sequence encoding a tandem affinity purification (TAP) tag in-frame with one allele, which should result in production of $\mathrm{N}$-terminally tagged $\mathrm{ZC} 3 \mathrm{H} 28$ (TAP-ZC3H28). RNAi in this line resulted in loss of the protein within $12 \mathrm{~h}$, and strong growth inhibition, confirming that $\mathrm{ZC} 3 \mathrm{H} 28$ is essential in bloodstream forms (Figure 1D, E). After a few days the cells resumed growth, presumably because of protein re-expression.

It is important to note that we were unable to delete the unmodified $\mathrm{ZC} 3 \mathrm{H} 28$ gene in the tagged cell line. This may mean that TAP-ZC3H28 is not fully functional, which in turn might have exacerbated the effect of the RNAi. Alternatively, it may be that the cells are unable to grow for long periods with only a single copy of the gene, whether the protein is tagged or not.

\section{Interactions of $\mathrm{ZC} 3 \mathrm{H} 28$ with other proteins}

From published resutls, it isn't clear whether $\mathrm{ZC} 3 \mathrm{H} 28$ is specifically associated with the MKT1 complex. We therefore examined interactions of $\mathrm{ZC} 3 \mathrm{H} 28$ with the different components using the yeast 2-hybrid assay (Figure 2A). In this assay, $\mathrm{ZC} 3 \mathrm{H} 28$ interacted with itself, and with PBP1, but not with MKT1. The N-terminal 527 residues (containing two poly(His) and one poly (Gln) segments) also interacted with itself and with PBP1; somewhat oddly, the N-terminal part of $\mathrm{ZC} 3 \mathrm{H} 28$ interacted with full-length $\mathrm{ZC} 3 \mathrm{H} 28$ only when the latter was in the "prey" configuration. Overall these results result suggest that $\mathrm{ZC} 3 \mathrm{H} 28$ can interact - probably directly - with PBP1.

To find out whether $\mathrm{ZC} 3 \mathrm{H} 28$ is associated with the MKT complex in vivo, we purified TAP$\mathrm{ZC} 3 \mathrm{H} 28$ and analyzed all co-purifying proteins by mass spectrometry (Supplementary Table S1, Figure 2B). Although MKT1, XAC1 and LSM12 consistently copurified, PBP1 was present in only 2 of the 3 replicates. Since TAP-ZC3H28 may not be fully functional, it is possible that the N-terminal tag interfered with some interactions. However the yeast two-hybrid constructs are also $\mathrm{N}$-terminal fusions, so tags alone cannot explain the contradictory results. Thus the issue of association of $\mathrm{ZC} 3 \mathrm{H} 28$ with the MKT1-PBP1 complex remains unresolved.

The mass spectrometry results were consistent with an association of $\mathrm{ZC} 3 \mathrm{H} 28$ with ribonucleoprotein particles or polysomes including numerous RNA-binding proteins and the two poly $(A)$ binding proteins. A large number of ribosomal proteins was present. Interestingly, $\mathrm{ZC} 3 \mathrm{H} 28$ was specifically associated with just one of the five known EIF4E-EIF4G translation initiation complexes, EIF4E4-EIF4G3. Various splicing factors also co-purified, including the putative regulators TSR1 (Gupta et al., 2014) HNRNPF/H (Gupta et al., 2013), which are probably also associated with cytosolic mRNAs; and TRRM1 which has been implicated in transcription elongation (Banuelos et al., 2019; Levy et al., 2015; Naguleswaran et al., 2015). Considering just proteins present in all three $\mathrm{ZC} 3 \mathrm{H} 28$ purifications, the RNA-binding proteins ALBA1, ALBA2, DRBD2, ZC3H34 and ZC3H41 were also associated with both PABP1 and PABP2; HNRNPF/H,TSR1, TRRM1, ZC3H39 and ZC3H40 were associated with PABP2, and ALBA3 with PABP1 (Zoltner et al., 2018). The protein of unknown function encoded by Tb927.10.9330, associated with ZC3H28, was also found with both PABPs (Zoltner et al., 2018). ZC3H28 also pulled down AGO1 (Shi et al., 2004a; Shi et al., 2004b), which does not copurify with the PABPs. RNA-binding proteins that were specific to the $\mathrm{ZC} 3 \mathrm{H} 28$ purification were PUF2 (Jha et al., 2014), RBP42 (Das et al., 2012), ZC3H18 (Benz et al., 2011) and ZC3H9. 
Overall these results would be consistent with $\mathrm{ZC} 3 \mathrm{H} 28$ being implicated in a range of mRNArelated processes.

\section{mRNA interactions of $\mathrm{ZC} 3 \mathrm{H} 28$}

To find out which mRNAs are preferentially bound by $\mathrm{ZC} 3 \mathrm{H} 28$, we purified the TAP-tagged protein, cleaved the tag with tobacco etch virus (TEV) protease and identified the co-purifying RNAs (Supplementary Table S2). The mRNA encoding ZC3H28 was 2.3-4.5 - fold enriched, consistent with some purification via the nascent polypeptide. Unexpectedly, VSG mRNA was not preferentially bound (Supplementary Table S2). In contrast, ZC $3 \mathrm{H} 28$ preferentially associated with long mRNAs, especially those with long 3 '-untranslated regions (Figure $3 A$ ), although the correlation was only partial, suggesting a degree of sequence specificity (Figure 3B). Consistent with the length bias, the list of 180 mRNAs that were at least 3-fold enriched in the bound fraction included 13 mRNAs encoding protein kinases and 12 encoding RNAbinding proteins, which tend to be long mRNAs; and there was no association with mRNAs encoding ribosomal proteins, which are mostly very short (Clayton, 2019; Erben et al., 2021) (Figure $3 \mathrm{C}$ ). A search for motifs using $>3 x$-enriched transcripts, with a set of length-matched controls with average binding ratios of less than 1 , revealed weak enrichment of poly $(U)$ and poly(AU) sequences. These are common in trypanosome 3'-UTRs and it turned out that the median $3^{\prime}$-UTR lengths of the length-matched controls were half those for the $3 x$ bound set. We therefore looked for motifs in the 3'-UTRs only, again using appropriately length-matched controls. This revealed significant enrichment of poly(AU) and polypurine tracts in the bound mRNA 3'-UTRs (Figure 3C). However, none of the motifs was present in all bound mRNAs, or exclusive to them. For example, the sequence "AUAUAUAUA" is present at least once in 49 of the 106 bound 3'-UTRs but also in 36 of the 103 unbound ones. The basis for the selectivity of $\mathrm{ZC} 3 \mathrm{H} 28$ is therefore not clear.

\section{The effect of $\mathrm{ZC} 3 \mathrm{H} 28$ depletion on the transcriptome}

The results so far would all be consistent with partially selective association of $\mathrm{ZC} 3 \mathrm{H} 28$ with translating mRNAs. From the tethering result we would expect association of $\mathrm{ZC} 3 \mathrm{H} 28$ to enhance expression, particularly at the mRNA level. To test the role of $\mathrm{ZC} 3 \mathrm{H} 28$ further we examined the effect of $\mathrm{ZC} 3 \mathrm{H} 28$ depletion on the transcriptome (Supplementary Tables $\mathrm{S} 3$ and S4). First, we looked at triplicate samples from cells grown without tetracycline, and after $10 \mathrm{~h}$ incubation with tetracycline. This time point was chosen because 10h RNAi induction was insufficient to affect growth (Supplementary Figure S2). Very few differences were found, so we also examined further duplicate samples after $14 \mathrm{~h}$ or $16 \mathrm{~h}$ with tetracycline, and $24 \mathrm{~h}$ either with or without tetracycline. Throughout this period the cells with tetracycline grew only very slightly slower than the controls, but after $24 \mathrm{~h}$ the numbers started to decrease (supplementary Figure S2). Intriguingly, a principal component analysis (Figure 4A) clearly separated the first set of controls (labelled -tet 1, -tet 2, and -tet3) from the second set (labelled A-tet and B-tet). The 10h induction (+tet 10h) clustered with its own control (Figure 4A), while the 24h induction (A-24h, B-24h) was quite similar to its control. In contrast, RNAi induction for $14 \mathrm{~h}$ and $16 \mathrm{~h}$ had very clear effects on the transcriptome.

These results were strange so we first looked at the difference between the two sets of controls. The cell densities for the triplicate samples were $5-6 \times 10^{5} / \mathrm{ml}$, whereas the duplicates were harvested at approximately $1 \times 10^{6} / \mathrm{ml}$. The mRNAs that were 1.5 -fold significantly (Padj $\left.<0.05\right)$ increased at the higher density included those encoding the procyclins and some proteins of mitochondrial metabolism, suggesting changes consistent with very early differentiation (Supplementary Table S4). Decreases of mRNAs encoding, for example, RNA polymerase I subunits, nucleotide transporters and translation elongation factor 2 would be consistent with slowing growth - although mRNAs encoding various RNA processing proteins, polymerase II subunits and flagellar proteins were increased. After $24 \mathrm{~h}$ of RNAi induction the cell densities were $1.3-1.6 \times 10^{6} / \mathrm{ml}$; perhaps this suppressed the RNAi effect. Amounts of total mRNA (Supplementary Figure S3A) and overall protein synthesis were not decreased by $\mathrm{ZC} 3 \mathrm{H} 28$ 
RNAi (Supplementary Figure S3B), but the rate of protein synthesis was reproducibly lower at densities above $1 \times 10^{6} / \mathrm{ml}$ (Supplementary Figure S3B) both with or without RNAi.

The effects of $\mathrm{ZC} 3 \mathrm{H} 28 \mathrm{RNAi}$ on the transcriptome peaked at about 14 hours after tetracycline addition (Figure 4A). More than 500 mRNAs were two-fold significantly increased, and nearly 700 decreased, at $14 \mathrm{~h}$; after $16 \mathrm{~h}$ this had decreased to 101 and 243 , respectively. We therefore concentrated on the effects after $14 \mathrm{~h}$. The strongest effects were clearly on mRNAs encoding ribosomal proteins (Figure 4B): $48 \%$ were more than 2 -fold increased and $77 \%$ more than 1.5-fold. In contrast mRNAs encoding RNA-binding proteins, protein kinases, citric acid cycle enzymes and amino acid transporters were relatively decreased (Figure 4B). The specificity here was unclear, since the effects were weakly inversely correlated with mRNA length (Figure 4C). (The precise correlation is unknown because many 3'-UTRs are annotated to be shorter than sequence coverage suggests.) Shorter RNAs, which tended not to be bound by $\mathrm{ZC} 3 \mathrm{H} 28$, also tended to increase after RNAi, and longer RNAs, which tended to be bound, decreased. The 39 mRNAs that were both at least 3-fold enriched with TAP-ZC3H28, and 2fold decreased after RNAi, had a median annotated length of $4.8 \mathrm{~kb}$; their products included 7 protein kinases and five RNA-binding proteins. In general, effects at $16 \mathrm{~h}$ were similar but slightly less pronounced.

Overall, there was no correlation between the degree of RNA binding and effects after RNAi (Figure 4D). However the mRNAs that were at least 3-fold enriched did have a 1.6-fold median decrease after loss of $\mathrm{ZC} 3 \mathrm{H} 28$, which is consistent with the ability of $\mathrm{ZC} 3 \mathrm{H} 28$ to increase mRNA levels in the tethering assay.

We finally looked for additional correlations. The bound mRNAs are mostly not cell-cycle regulated (Archer et al., 2011) and there was no correlation with developmental regulation of either mRNA level (Fadda et al., 2014) or translation (Antwi et al., 2016). Interestingly, however, binding of mRNAs to $\mathrm{ZC} 3 \mathrm{H} 28$ was clearly negatively correlated with the ribosome density on the coding region (Antwi et al., 2016) (Figure 5A). This appears not to be secondary to other mRNA characteristics, since there is no correlation between ribosome density on the coding region and mRNA length or 3'-UTR length (Supplementary Table S4). There was also no correlation between the effects of RNAi and either ribosome density or mRNA half-life, and no correlation either between $\mathrm{ZC} 3 \mathrm{H} 28$ mRNA binding and mRNA half-life. This result, combined with that from tethering, suggests that $\mathrm{ZC} 3 \mathrm{H} 28$ might act to protect poorly-translated mRNAs from degradation.

\section{Discussion}

Our cumulative results suggest that $\mathrm{ZC} 3 \mathrm{H} 28$ acts to decrease translation of preferentially associated mRNAs. ZC3H28 has only a single zinc finger. A crystal structure of the two $\mathrm{CCCH}$ domains of TIS11 showed that each $\mathrm{CCCH}$ domain could bind specifically to four nucleotides (Hudson et al., 2004), and that the region 5' to the zinc finger contributed to specificity. With only a single zinc finger, not much specificity would be expected unless $\mathrm{ZC} 3 \mathrm{H} 28$ acts as a multimer. We found that bound mRNAs tended to be relatively long, especially in the 3'untranslated region, with long low-complexity sequences. Several different low complexity sequences were seen, and there was no discernable base specificity.

The effects of $\mathrm{ZC} 3 \mathrm{H} 28$ depletion on the transcriptome where quite surprising. First, we found clear indications that non-depleted cells at a density of about $1 \times 10^{6} / \mathrm{ml}$ were already starting to undergo changes typical of differentiation to the stumpy form, although these were Lister 427 parasites which are incapable of growth arrest and stumpy differentiation. These cells also had a somewhat lower translation rate than cells at $5 \times 10^{5} / \mathrm{ml}$. After $14 \mathrm{~h}$ of RNAi induction - which corresponds to less than $5 \mathrm{~h}$ without $\mathrm{ZC} 3 \mathrm{H} 28$ (Figure $1 \mathrm{E}$ ), depleted cells (at densities around $7 \times 10^{5} / \mathrm{ml}$ ) showed significant effects on over $1000 \mathrm{mRNAs}$, especially preferential loss of longer transcripts. Many of these effects could be indirect since most of the decreased mRNAs were not actually bound by tagged $\mathrm{ZC} 3 \mathrm{H} 28$. However only $2 \mathrm{~h}$ later the differences had begun to diminish and after $24 \mathrm{~h}$, at $1 \times 10^{6} / \mathrm{ml}$, the transcriptomes had reverted to be similar to those of controls. These results suggest that $\mathrm{ZC} 3 \mathrm{H} 28$ is most important in growing parasites. 
As is the case for many experiments with mRNA-binding proteins, none of the correlations is very strong, because the final status of mRNAs will be determined not by $\mathrm{ZC} 3 \mathrm{H} 28$ alone, but by the additional actions of all the other regulatory molecules.

Tethering of $\mathrm{ZC} 3 \mathrm{H} 28$ to a reporter increased the amount of mRNA without a corresponding increase in protein, suggesting that translation was suppressed. Consistent with this, $\mathrm{ZC} 3 \mathrm{H} 28$ is preferentially associated with mRNAs that have low ribosome occupancy in their coding regions. A possible mechanism for the two effects could be sequestration of mRNAs in nontranslating compartments. Intriguingly, C-terminally GFP-tagged $\mathrm{ZC} 3 \mathrm{H} 28$ was found in cytoplasmic aggregates in slightly starvation-stressed procyclic forms (see http://tryptag.org/?query=Tb927.9.9450), although it was not enriched in granules purified after more prolonged starvation (Fritz et al., 2015). Aggregation is expected to occur in proteins with long poly(His) or poly $(\mathrm{Gln})$ tracts, as seen in $\mathrm{ZC} 3 \mathrm{H} 28$, and unsurprisingly, in the yeast two-hybrid system, $\mathrm{ZC} 3 \mathrm{H} 28$ showed self-interaction. Intriguingly, mRNAs that are found in procyclic granules did show preferential association with $\mathrm{ZC} 3 \mathrm{H} 28$ in bloodstream forms (Figure 5B). Overall, our results suggest that $\mathrm{ZC} 3 \mathrm{H} 28$ is implicated in controlling translation of a subset of mRNAs in growing trypanosomes.

\section{Materials and Methods}

\section{Trypanosome culture and modification}

The experiments in this study were carried out using monomorphic T. brucei Lister 427 bloodstream form parasites constitutively expressing the Tet-repressor (Alibu et al. 2005). The parasites were cultured at $37^{\circ} \mathrm{C}$ as routinely in $\mathrm{HMI}-9$ medium supplemented with $10 \%$ heat inactivated fetal bovine serum $(\mathrm{v} / \mathrm{v}), 1 \%(\mathrm{v} / \mathrm{v})$ penicillin/streptomycin solution (Labochem international, Germany), $15 \mu \mathrm{M} \mathrm{L}$-cysteine, and $0.2 \mathrm{mM} \beta$-mercaptoethanol in the presence of $5 \%$ CO2 and $95 \%$ humidity (Hirumi and Hirumi, 1989). During proliferation, the cells were diluted to $1 \times 10^{5}$ cells $/ \mathrm{ml}$ and maintained in density between $0.2-2 \times 10^{6}$ as described in (Clayton, 1999). Cell densities were determined using a Neubauer chamber. For generation of stable cell lines, $\sim 1-2 \times 10^{7}$ cells were transfected by electroporation with $10 \mu \mathrm{g}$ of linearized plasmid at $1.5 \mathrm{kV}$ on an AMAXA Nucleofector. Selection of newly transfectants was done after addition of appropriate antibiotic at the following concentrations: $1 \mu \mathrm{g} / \mathrm{ml}$ puromycin, $2.5 \mu \mathrm{g} / \mathrm{ml}$ phleomycin (InvivoGen), $5 \mu \mathrm{g} / \mathrm{ml}$ hygromycin B (Calbio-chem. $10 \mu \mathrm{g} / \mathrm{ml}$ blasticidin (InvivoGen). Independent clones were obtained by serial dilution.

\section{Genetic manipulation of trypanosomes}

A cell line with in-situ TAP-ZC3H28 gene was generated by replacing one endogenous copy of $\mathrm{ZC} 3 \mathrm{H} 28$ with a gene encoding N-terminally TAP tagged $\mathrm{ZC} 3 \mathrm{H} 28$. For this purpose, a construct with puromycin resistance gene plus a TAP tag cassette was flanked on the 5'-end with a fragment of ZC3H28 5'-UTR. Also, downstream on the 3'-end, the $\mathrm{N}$ terminal region of $\mathrm{ZC} 3 \mathrm{H} 28$ ORF was cloned in frame with the TAP tag. Prior to transfection, the plasmid (pHD3236) was cut with Sacl and Apal enzymes to allow homologous recombination. Using the cell lines expressing the in-situ N-TAP ZC3H28, we were unable to knock-out the other copy of $\mathrm{ZC} 3 \mathrm{H} 28$. Gene fragments for RNAi were selected based on default settings of the RNAit software (Redmond et al., 2003) and cloned into the pHD 1146 plasmid. For the tethering assays, cell lines constitutively expressing the CAT reporter with boxB and the actin 3'-UTR were co-transfected with plasmids encoding the $\mathrm{ZC} 3 \mathrm{H} 28$ in fusion with the $\lambda \mathrm{N}$-peptide and a myc tag (Erben et al., 2014). The primers and plasmids used are listed in Supplementary Table S5.

\section{DNA extraction}

Genomic DNA from T. brucei was isolated using 1-2 $\times 10^{8}$ cells as follows. The cell pellet was collected by centrifugation ( $2300 \mathrm{rpm}, 8$ minutes), washed once in cold 1x PBS, and lysed in $0.5 \mathrm{ml}$ of EB buffer (10 mM Tris- $\mathrm{HCl} \mathrm{pH} \mathrm{8.0,10} \mathrm{mM} \mathrm{NaCl,} 10 \mathrm{mM}$ EDTA). RNA was digested with addition of $12 \mu \mathrm{l}$ RNAse A ( $1 \mathrm{mg} / \mathrm{ml}$ stock solution, Sigma-Aldrich) at $37^{\circ} \mathrm{C}$ for 30 minutes. Proteins were precipitated using $200 \mu \mathrm{l}$ ice-cold $5 \mathrm{M}$ ammonium acetate followed by 
centrifugation at maximum speed for 5 minutes. The supernatant containing the DNA was transferred to a new tube. The DNA was then precipitated with $0.7 x$ isopropanol followed by centrifugation at maximum speed for 15 minutes. The pellet was then washed once with $75 \%$ ethanol to remove salts and then again with $100 \%$ ethanol followed by centrifugation for 5 minutes. The DNA pellet was then dried for approximately 5 minutes and dissolved in TE buffer (10 mM Tris pH 7.5, $1 \mathrm{mM}$ EDTA pH 8.0) at $37^{\circ} \mathrm{C}$. The concentration was measured using a Nanodrop. PCR was done using Taq Polymerase according to the manufacturer's instructions (New England Biolabs).

\section{RNA manipulation}

To identify RNAs bound to $\mathrm{ZC} 3 \mathrm{H} 28$, approximately $1 \times 10^{9}$ cells expressing in-situ N-TAP tagged $\mathrm{ZC} 3 \mathrm{H} 28$ with a concentration of $1 \times 10^{6}$ cells $/ \mathrm{ml}$ were pelleted by centrifugation at 3000 rpm for 13 minutes at $4^{\circ} \mathrm{C}$. The pellet was washed twice in cold $1 \mathrm{X}$ PBS and collected by centrifugation at $2300 \mathrm{rpm}$ for 8 minutes at $4^{\circ} \mathrm{C}$ and then snap frozen in liquid nitrogen. The RNA immunoprecipitation was done essentially as described in (Mugo \& Clayton, 2017). The cell pellet was lysed in $1 \mathrm{ml}$ of the lysis buffer $\left(20 \mathrm{mM}\right.$ Tris $\mathrm{pH} 7.5,5 \mathrm{mM} \mathrm{MgCL}_{2}, 0.1 \%$ IGEPAL, $1 \mathrm{mM}$ DTT, $100 \mathrm{U}$ RNAsin, $10 \mu \mathrm{g} / \mathrm{ml}$ leupeptin, $10 \mu \mathrm{g} / \mathrm{ml}$ Aprotinin) by passing 20 times through a $21 \mathrm{G} \times 1 / 2$ needle using a $1 \mathrm{ml}$ syringe and 20 times through a $27 \mathrm{G} \times 3 / 4$ needle using a $1 \mathrm{ml}$ syringe. The lysate was cleared by centrifugation at $15,000 \mathrm{~g}$ for 15 minutes at $4^{\circ} \mathrm{C}$ and the supernatant was transferred to a new tube. The salt concentration was then adjusted to 150 $\mathrm{mM} \mathrm{KCl}$. The cell extracts were afterwards incubated with $40 \mu \mathrm{l}$ of IgG-coupled magnetic beads (Dynabeads ${ }^{\mathrm{TM}} \mathrm{M}-280$ Tosylactivated, Invitrogen) for 3 hours at $4^{\circ} \mathrm{C}$ and the flow-through (unbound) fraction was collected by magnetic separation as the negative control. peqGOLD TriFast $^{\mathrm{TM}} \mathrm{FL}$ REAGENT was added to the unbound fractions and kept at $-80^{\circ} \mathrm{C}$ for further RNA extraction. After three washing with IP buffer $(20 \mathrm{mM}$ Tris $\mathrm{pH} 7.5,5 \mathrm{mM} \mathrm{MgCL} 2,150 \mathrm{mM}$ $\mathrm{KCl}, 0.1 \%$ IGEPAL, $1 \mathrm{mM}$ DTT, $100 \cup$ RNAsin, $10 \mu \mathrm{g} / \mathrm{ml}$ leupeptin, $10 \mu \mathrm{g} / \mathrm{ml}$ Aprotinin), the tagged protein was eluted from beads using 150 units of TEV protease at $4^{\circ} \mathrm{C}$ for overnight. The eluate was transferred to a fresh tube, two volumes of peqGOLD TriFast ${ }^{\mathrm{TM}} \mathrm{FL}$ reagent were added, and samples were stored at $-80^{\circ} \mathrm{C}$ until further processing. RNA was isolated from released and bound fractions according the manufacturer's instructions. Total RNA from the unbound and the eluate fraction were depleted of ribosomal RNA (rRNA) using RNAse H and a cocktail of 131 DNA oligos (50 bases) complementary to the trypanosome rRNAs. The rRNAs hybridized to the oligonucleotides were digested with RNAse H (NEB, M0297S) as previously described in (Minia et al., 2016). Following rRNA depletion, the samples were subjected to DNAse I treatment in order to remove any trace of oligonucleotides using the Turbo $^{\mathrm{TM}}$ DNAse kit (Invitrogen, ThermoScientific). The RNA samples were afterward purified using the RNA Clean \& Concentrator ${ }^{\mathrm{TM}}-5$ kit (ZYMO RESEARCH) following the manufacturer's instructions. The recovered purified RNA from both bound and unbound samples were then analyzed by RNA-Seq.

The purified RNA (5-10 $\mu \mathrm{g})$ was mixed with 2X RNA loading dye $(1,6 \mathrm{X}$ MOPS buffer, $7 \%$ formaldehyde, $65 \%$ formamide, $50 \mu \mathrm{g} / \mathrm{ml}$ ethidium bromide, $0.025 \%$ bromophenol blue), denatured for 10 minutes at $65^{\circ} \mathrm{C}$ and then resolved on formaldehyde agarose gel. The RNA was afterwards blotted onto Nylon membranes (Amersham Hybond-N+, GE Healthcare, RPN203B) with 10X saline-sodium citrate buffer (SSC) by capillary transfer overnight. The RNA was then cross-linked to positively charged membranes using a UV-crosslinker (Stratagene UV Stratalinker 2400, 2×240 mJoules) and stained with methylene blue (SERVA) for 10 minutes. The northern blots were pre-hybridized in hybridization solution for $1 \mathrm{~h}$ at $65^{\circ} \mathrm{C}$ and then hybridized in the same solution with the appropriate $\left(\alpha^{32} \mathrm{P}\right)$ dCTP radioactively labelled DNA probes from CAT and tubulin genes for overnight at $65^{\circ} \mathrm{C}$. Labelling the DNA probes was done with Prime-IT RmT Random Primer Labelling Kit, Stratagene. The following day, the blot was washed twice for 10 minutes at room temperature with wash solution 1 ( $2 x$ SSC, $0.1 \%$ SDS), twice for 10 minutes with wash solution 2 (1x SSC buffer, $0.1 \%$ SDS) and twice for 10 minutes at $65^{\circ} \mathrm{C}$ with wash solution $3(0.1 \times \mathrm{SSC}, 0.1 \%$ SDS). For spliced leader detection, a 39-mer oligonucleotide complementary to the spliced leader was labelled with 
[Y32P]-ATP using T4 polynucleotide kinase (NEB) and incubated with the membrane overnight at $42^{\circ} \mathrm{C}$. Afterwards, the blots were exposed to autoradiography films and the signals were detected with the phosphorimager (Fuji, FLA7000). The images were processed and quantified using ImageJ.

\section{RNA sequencing and data analysis}

RNA sequencing was done at the CellNetworks Deep Sequencing Core Facility at the University of Heidelberg. NEBNext Ultra RNA Library Prep Kit for Illumina (New England BioLabs Inc.) was used for library preparation. The libraries were multiplexed (6 samples per lane) and sequenced with a Nextseq 550 system, generating 75 bp single-end sequencing reads. This was done using a custom pipeline (Leiss et al., 2016) that incorporated the following steps. Before analysis, the quality of the raw sequencing data was checked using FastQC (http://www. bioinformatics.babraham.ac.uk/projects/fastqc). Cutadapt (Martin, 2011) was used to remove sequencing primers, poly $(A)$ tails and spliced leaders. After primer removal, the sequencing data were aligned to $T$. brucei 927 reference genome using Bowtie2 (Langmead \& Salzberg, 2012), allowing 1 alignment per read, then sorted and indexed using SAMtools (Li et al., 2009). Reads aligning to open reading frames, annotated 3'-untranslated regions, and functional non-coding RNAs were counted. The alignment and counting were then repeated with Lister 427 genome (2018 assembly) (Müller et al., 2018). For comparative and enrichment analyses, we used a list of unique genes modified from (Siegel et al., 2010) in order to avoid giving excessive weight to repeated genes and multigene families. For the RIP-Seq, the reads per millions were counted and the ratios of eluate versus unbound were calculated. An mRNA was considered as "bound mRNA" if the lowest ratio was at least 3 . The motif enrichment search was done using MEME (Bailey, 2011). Annotated 3'-UTRs were downloaded from TritrypDB. Analysis of differentially expressed genes after ZC3H28 RNAi was done in $\mathrm{R}$ using the DESeqUI (Leiss \& Clayton, 2016), a customized version of DESeq2 package (Love et al., 2014) adapted for trypanosome transcriptomes. Statistical analyses were done using $\mathrm{R}$ and Microsoft Excel.

\section{Yeast two-hybrid assays}

The Matchmaker Yeast two-hybrid system (Clontech) was used to test direct protein-protein interactions according to the manufacturer's instructions. The coding sequence of $\mathrm{ZC} 3 \mathrm{H} 28$ was PCR-amplified from genomic DNA and cloned into pGBKT7 and pGADT7 plasmids. The prey and the baits plasmids of $\mathrm{ZC} 3 \mathrm{H} 28$ as well as those of the MKT1complex proteins were co-transformed pairwise into $\mathrm{AH} 109$ yeast strains. Selection was done initially on double dropout (DDO) plates (i.e., SD medium lacking Tryptophan and Leucine) to check expression of both bait and prey. The growth was then checked on quadruple drop-out (QDO) plates (i.e., lacking Tryptophan, Leucin, Histidine and Adenine) that indicates positive interactions. The interaction between p53 and SV40 large T-antigen and the combination of LaminC and SV40 large $T$ antigen served as positive and negative controls, respectively.

\section{Protein purification and mass spectrometry analysis}

Approximately $1 \times 10^{9}$ cells expressing either in-situ N-TAP ZC3H28 (pHD3236) or tet-inducible GFP-TAP (pHD1743) with a concentration of $1 \times 10^{6} \mathrm{cell} / \mathrm{s} / \mathrm{ml}$ were harvested by centrifugation. For each cell line, three technical replicates were done without RNAse A treatment. The cell pellet was resuspended in $10 \mathrm{ml}$ of cold 1x PBS and centrifuged at $2800 \mathrm{rpm}$ for 8 minutes at $4^{\circ}$ and the pulldowns were done as described above, except that after TEV cleavage, the eluate was collected by magnetic separation. To remove His-tagged TEV, $10 \mu \mathrm{L}$ of equalization buffer ( $200 \mathrm{mM}$ sodium phosphate, $600 \mathrm{mM}$ sodium chloride, $0.1 \%$ Tween-20, $60 \mathrm{mM}$ imidazole, $\mathrm{pH} 8.5$ ), as well as $30 \mu \mathrm{L}$ of Ni-NTA-magnetic beads were added and incubated with the samples for $30 \mathrm{~min}$ at $20^{\circ} \mathrm{C}$ while rotating. Ni-NTA magnetic beads were separated using a magnetic rack and the supernatant was collected and stored in 6X Laemmli buffer at $-80^{\circ} \mathrm{C}$. Eluted proteins were separated on $12 \%$ SDS-polyacrylamide gel until the running front had migrated roughly $2 \mathrm{~cm}$, thereafter the gel was stained with Coomassie blue and destained with destaining solution (10\% acetic acid, $50 \%$ methanol in $\mathrm{H}_{2} \mathrm{O}$ ). Two areas 
per lane were cut and analyzed in the ZMBH Mass Spectrometry facility via the Ultimate 3000 liquid chromatography system directly coupled to an Orbitrap Elite mass spectrometer (Thermo Fisher). MS spectra (m/z 400-1600) were acquired in the Orbitrap at $60,000(\mathrm{~m} / \mathrm{z}$ $400)$ resolution. Fragmentation in CID cell was performed for up to 10 precursors. MS2 spectra were acquired at rapid scan rate. Raw files were processed using MaxQuant (version 1.5.3.30; J. Cox, M. Mann, Nat Biotechnol 2008, 26, 1367) for peptide identification and quantification. MS2 spectra were searched against the TriTrypDB-8.1TREU927-AnnotatedProteins-1 database (containing 11567 sequences). Data were analyzed quantitatively and plotted using Perseus software (Version 1.6.15.0).

\section{Protein detection by western blotting}

For western blotting, $1-5 \times 10^{6}$ cells were collected by centrifugation at $3000 \mathrm{rpm}$ for 5 minutes, washed twice in ice-cold 1x PBS, lysed in $2 \times$ Laemmli buffer and heated at $95^{\circ} \mathrm{C}$ for 10 minutes. The protein samples were separated using $12 \%$ SDS-PAGE gels, and processed as described previously in Minia et al., 2016. The following antibodies were used for specific protein detection: anti-PAP (1: 1:5000, rabbit, Sigma), anti-myc (mouse, 1:1000); anti-rabbit IgG (for pull-downs). The proteins were detected by enhanced chemiluminescence according to the manufacturer's instructions (Amersham Biosciences).

\section{CAT Assay}

To perform the CAT assay experiment, approximately $2 \times 10^{7}$ cells expressing the CAT reporter gene were harvested at $2300 \mathrm{rpm}$ for 8 minutes and washed three times with $1 \mathrm{x}$ cold PBS. The pellet was re-suspended in $200 \mu \mathrm{l}$ of CAT buffer $(100 \mathrm{mM}$ Tris-HCl pH 7.8$)$ and lysed by freeze-thawing three times using liquid nitrogen and a $37^{\circ} \mathrm{C}$ heating block. The supernatants were then collected by centrifugation at $15,000 \times \mathrm{g}$ for $5 \mathrm{~min}$ and kept on ice. The protein concentrations were determined by Bradford assay (BioRad) according to the manufacturer's protocol. For each setup, $0.5 \mu \mathrm{g}$ of protein in $50 \mu \mathrm{l}$ of CAT buffer, $10 \mu \mathrm{l}$ of radioactive butyryl CoA $\left({ }^{14} \mathrm{C}\right), 2 \mu \mathrm{l}$ of chloramphenicol (stock: $40 \mathrm{mg} / \mathrm{ml}$ ), $200 \mu \mathrm{l}$ of CAT buffer and $4 \mathrm{ml}$ of scintillation cocktail were mixed in a Wheaton scintillation tube HDPE (neoLab \#9-0149). The incorporation of radioactive acetyl group on chloramphenicol was measured using program 7 of Beckman LS 6000IC scintillation counter.

\section{Pulse labelling}

For each time point, approximately $4 \times 10^{6}$ cells were collected at room temperature. The pellet was washed twice with ice-cold 1x PBS followed by centrifugation at $4,000 \mathrm{~g}$ for 3 minutes. The cell pellet was then resuspended in $400 \mu$ l labeling medium (Dulbecco's Modified Eagle Medium (Gibco) lacking L-methionine and cysteine) at $37^{\circ} \mathrm{C}$ for 1 hour. $2 \mu \mathrm{l}$ of L-[ $\left.{ }^{35} \mathrm{~S}\right]$ methionine (about $20 \mu \mathrm{Ci}$ ) was then added. The cells were incubated for $1 \mathrm{~h}$ at $37^{\circ} \mathrm{C}$ and afterwards collected by centrifugation at $4,000 \mathrm{~g}$ for 3 minutes at RT. The pellet was washed twice with $1 \mathrm{x}$ PBS and then resuspended in in $15 \mu \mathrm{l}$ of Laemmli lysis buffer. The proteins were separated in a $12 \%$ SDS gel. The gel was the dried unto a Whatman paper, then exposed to autoradiography films and the signals were detected with the phosphorimager (Fuji, FLA7000).

The labeling medium was Dulbecco's modified Eagle's medium (Gibco, high-glucose, containing pyridoxine hydrochloride, lacking L-glutamine, sodium pyruvate, L-methionine, and L-cysteine), supplemented with $25 \mathrm{mM}$ HEPES, $2 \mathrm{mM}$ glutamine, $0.1 \mathrm{mM}$ hypoxanthine, $0.0028 \%$ b-mercaptoethanol, $0.05 \mathrm{mM}$ bathocupronsulfate, and $10 \%$ heat-inactivated fetal calf serum (previously dialyzed against 30 mM HEPES, pH 7.3, $150 \mathrm{mM} \mathrm{NaCl}$ ).(Leiss et al., 2016). The transcriptome data were analysed using DeSeqU1 (Leiss \& Clayton, 2016).

\section{Data availability}

The transcriptomes are available with accession numbers E-MTAB-10674 (ZC3H28associated RNA) and E-MTAB-10751 (effect of RNAi). The mass spectrometry proteomics data have been deposited to the ProteomeXchange Consortium via the PRIDE partner repository (Perez-Riverol et al., 2019) with the dataset identifier PXD027792. 


\section{Acknowledgements}

This work was partially funded by Deutsche Forschungsgemeinschaft grant number $\mathrm{Cl} 112 / 28$ 1 to $\mathrm{CC}$, and by core support from the state of Baden-Württemberg. We thank Claudia Helbig and Ute Leibfried for technical assistance, David Ibberson of the Bioquant sequencing facility (University of Heidelberg) for cDNA library construction and RNA sequencing. Mass spectrometry was done in the ZMBH Core Facility by Thomas Ruppert and Sabine Merker. We are indebted to Prof. Dr. Nina Papavasiliou (DKFZ, University of Heidelberg) and Prof. Dr. Luise Krauth-Siegel (BZH, University of Heidelberg) for allowing us to share their laboratories including equipment and reagents after the flood in the $\mathrm{ZMBH}$. We acknowledge the support of Andrea Zanotti (AG Lemberg) for the assistance in the pulse labelling experiment.

\section{Author contributions}

T.B. performed all the experiments. T.B. and C.C. were both involved in conceptualization, methodology, data curation, formal analysis, validation, investigation and visualization, writingoriginal draft, review and editing. C. C. was responsible for supervision, funding acquisition, and project administration.

\section{Conflict of interest}

The authors declare that they have no conflicts of interest. 


\section{References}

Alsford, S., Turner, D., Obado, S., Sanchez-Flores, A., Glover, L., Berriman, M., HertzFowler, C. and Horn, D. (2011). High throughput phenotyping using parallel sequencing of RNA interference targets in the African trypanosome. Genome Res., 21, 915-924. doi: 10.1101/gr.115089.110.

Antwi, E., Haanstra, J., Ramasamy, G., Jensen, B., Droll, D., Rojas, F., Minia, I., Terrao, M., Mercé, C., Matthews, K., Myler, P., Parsons, M. and Clayton, C. (2016). Integrative analysis of the Trypanosoma brucei gene expression cascade predicts differential regulation of mRNA processing and unusual control of ribosomal protein expression. BMC Genomics, 17, 306. doi: 10.1186/s12864-016-2624-3.

Archer, S., Inchaustegui, D., de Queiroz, R. and Clayton, C. (2011). The cell-cycle regulated transcriptome of an early-branching eukaryote. PloS One 6, e18425.

Bailey, T. (2011). DREME: Motif discovery in transcription factor ChIP-seq data. Bioinformatics, 27, 1653-1659.

Banuelos, C. P., Levy, G. V., Nittolo, A. G., Roser, L. G., Tekiel, V. and Sanchez, D. O. (2019). The Trypanosoma brucei RNA-Binding Protein TbRRM1 is Involved in the Transcription of a Subset of RNA Pol II-Dependent Genes. J Eukaryot Microbiol. doi: 10.1111/jeu.12716.

Benz, C., Mulindwa, J., Ouna, B. and Clayton, C. (2011). The Trypanosoma brucei zinc finger protein $\mathrm{ZC} 3 \mathrm{H} 18$ is involved in differentiation. Mol Biochem Parasitol, 177, 148151. doi: DOI: 10.1016/j.molbiopara.2011.02.007.

Clayton, C. (2019). Control of gene expression in trypanosomatids: living with polycistronic transcription. Royal Society Open Biology, 9, 190072. doi: 10.1098/rsob.190072.

Clayton, C. E. (1999). Genetic manipulation of Kinetoplastida. Parasitol. Today, 15, 372-378.

Das, A., Morales, R., Banday, M., Garcia, S., Hao, L., Cross, G. A., Estevez, A. M. and Bellofatto, V. (2012). The essential polysome-associated RNA-binding protein RBP42 targets mRNAs involved in Trypanosoma brucei energy metabolism. Rna, 18, 19681983. doi: 10.1261/rna.033829.112.

Dean, S., Sunter, J. and Wheeler, R. (2016). TrypTag.org: A trypanosome genome-wide protein localisation resource. Trends Parasitol., 33, 80-82.

Erben, E., Fadda, A., Lueong, S., Hoheisel, J. and Clayton, C. (2014). Genome-wide discovery of post-transcriptional regulators in Trypanosoma brucei. PLoS Pathog, 10, e1004178. doi: doi:10.1371/journal.ppat.1004178.

Erben, E., Leiss, K., Liu, B., Inchaustegui Gil, D., Helbig, C. and Clayton, C. (2021). Insights into the functions and RNA binding of Trypanosoma brucei ZC3H22, RBP9 and DRBD7. Parasitology, 148, 1186 - $1195 . \quad$ doi: https://doi.org/10.1017/S0031182021000123.

Fadda, A., Ryten, M., Droll, D., Rojas, F., Färber, V., Haanstra, J., Bakker, B., Matthews, K. and Clayton, C. (2014). Transcriptome-wide analysis of mRNA decay reveals complex degradation kinetics and suggests a role for co-transcriptional degradation in determining mRNA levels. Mol Microbiol, 94, 307-326. doi: 10.1111/mmi.12764.

Fritz, M., Vanselow, J., Sauer, N., Lamer, S., Goos, C., Siegel, T., Subota, I., Schlosser, A., Carrington, M. and Kramer, S. (2015). Novel insights into RNP granules by employing the trypanosome's microtubule skeleton as a molecular sieve. Nucleic Acids Res. , 43, 8013-8032.

Gupta, S. K., Chikne, V., Eliaz, D., Tkacz, I. D., Naboishchikov, I., Carmi, S., Waldman Ben-Asher, H. and Michaeli, S. (2014). Two splicing factors carrying serine-arginine motifs, TSR1 and TSR1IP, regulate splicing, mRNA stability, and rRNA processing in Trypanosoma brucei. RNA Biol, 11.

Gupta, S. K., Kosti, I., Plaut, G., Pivko, A., Tkacz, I. D., Cohen-Chalamish, S., Biswas, D. K., Wachtel, C., Waldman Ben-Asher, H., Carmi, S., Glaser, F., Mandel-Gutfreund, Y. and Michaeli, S. (2013). The hnRNP F/H homologue of Trypanosoma brucei is differentially expressed in the two life cycle stages of the parasite and regulates 
splicing and mRNA stability. Nucleic Acids Res, 41, 6577-6594. doi: 10.1093/nar/gkt369.

Hudson, B., Martinez-Yamout, M., Dyson, H. and Wright, P. (2004). Recognition of the mRNA AU-rich element by the zinc finger domain of TIS11d. Nat Struct Mol Biol, 11, 257-264.

Jha, B., Fadda, A., Merce, C., Mugo, E., Droll, D. and Clayton, C. (2014). Depletion of the trypanosome pumilio domain protein PUF2 causes transcriptome changes related to coding region length. Eukaryot Cell, 13, 664-674. doi: doi: 10.1128/EC.00018-14.

Langmead, B. and Salzberg, S. (2012). Fast gapped-read alignment with Bowtie 2. Nature Methods 9, 357-359.

Leiss, K. and Clayton, C. (2016). DESeqUI - Trypanosome RNAseq analysis made easy. Zenodo, doi:10.5281/zenodo.165132.

Leiss, K., Merce, C., Muchunga, E. and Clayton, C. (2016). TrypRNAseq - A easy to use pipeline for Trypanosoma RNAseq data. Zenodo, http://doi.org/10.5281/zenodo.158920.

Levy, G. V., Banuelos, C. P., Nittolo, A. G., Ortiz, G. E., Mendiondo, N., Moretti, G., Tekiel, V. S. and Sanchez, D. O. (2015). Depletion of the SR-Related Protein TbRRM1 Leads to Cell Cycle Arrest and Apoptosis-Like Death in Trypanosoma brucei. PloS One, 10, e0136070. doi: 10.1371/journal.pone.0136070.

Li, H., Handsaker, B., Wysoker, A., Fennell, T., Ruan, J., Homer, N., Marth, G., Abecasis, G. and Durbin, R. (2009). The Sequence Alignment/Map format and SAMtools. Bioinformatics, 25, 2078-2079.

Love, M., Huber, W. and Anders, S. (2014). Moderated estimation of fold change and dispersion for RNA-Seq data with DESeq2. Genome Biol, 15, 550.

Lueong, S., Merce, C., Fischer, B., Hoheisel, J. and Erben, E. (2016). Gene expression regulatory networks in Trypanosoma brucei: insights into the role of the mRNA-binding proteome. Mol Microbiol, 100, 457-471.

Martin, M. (2011). Next Generation Sequencing Data Analysis: Cutadapt removes adapter sequences from high-throughput sequencing reads. EMBnetjournal, 17, 1.

Melo do Nascimento, L., Egler, F., Arnold, K., Papavisiliou, N., Clayton, C. and Erben, E. (2021). Functional insights from a surface antigen mRNA-bound proteome. Elife, 10, e68136. doi: https://doi.org/10.7554/eLife.68136.

Minia, I., Merce, C., Terrao, M. and Clayton, C. (2016). Translation regulation and RNA granule formation after heat shock of procyclic form Trypanosoma brucei: many heatinduced mRNAs are increased during differentiation to mammalian-infective forms. PLoS Negl Trop Dis, 10, e0004982.

Mugo, E. and Clayton, C. (2017). Expression of the RNA-binding protein RBP10 promotes the bloodstream-form differentiation state in Trypanosoma brucei. PLoS Pathog, 13, e1006560. doi: 10.1371/journal.ppat.1006560.

Müller, L., Cosentino, R., Förstner, K., Guizetti, J., Wedel, C., Kaplan, N., Janzen, C., Arampatzi, P., Vogel, J., Steinbiss, S., Otto, T., Saliba, A.-E., Sebra, R. and Siegel, T. (2018). Genome organization and DNA accessibility control antigenic variation in trypanosomes. Nature, 563, 121-125. doi: /10.1038/s41586-018-0619-8.

Naguleswaran, A., Gunasekera, K., Schimanski, B., Heller, M., Hemphill, A., Ochsenreiter, T. and Roditi, I. (2015). Trypanosoma brucei RRM1 is a nuclear RNAbinding protein and modulator of chromatin structure. MBio, 6, e00114. doi: 10.1128/mBio.00114-15.

Nascimento, L., Terrao, M., Marucha, K., Liu, B., Egler, F., Helbig, C. and Clayton, C. (2020). The RNA-associated proteins MKT1 and MKT1L form alternative PBP1containing complexes in Trypanosoma brucei. J Biol Chem, 295, 10940-10955. doi: 10.1074/jbc.RA120.013306.

Perez-Riverol, Y., Csordas, A., Bai, J., Bernal-Llinares, M., Hewapathirana, S., Kundu, D., Inuganti, A., Griss, J., Mayer, G., Eisenacher, M., Pérez, E., Uszkoreit, J., Pfeuffer, J., Sachsenberg, T., Yilmaz, S., Tiwary, S., Cox, J., Audain, E., Walzer, M., Jarnuczak, A., Ternent, T., Brazma, A. and Vizcaíno, J. (2019). The PRIDE 
database and related tools and resources in 2019: improving support for quantification data. Nucleic Acids Res 47, D442-D450.

Redmond, S., Vadivelu, J. and Field, M. C. (2003). RNAit: an automated web-based tool for the selection of RNAi targets in Trypanosoma brucei. Mol. Biochem. Parasitol., 128, 115-118.

Shi, H., Djikeng, A., Tschudi, C. and Ullu, E. (2004a). Argonaute protein in the early divergent eukaryote Trypanosoma brucei: control of small interfering RNA accumulation and retroposon transcript abundance. Mol Cell Biol, 24, 420-427.

Shi, H., Ullu, E. and Tschudi, C. (2004b). Function of the Trypanosome Argonaute 1 protein in RNA interference requires the N-terminal RGG domain and arginine 735 in the Piwi domain. J Biol Chem, 279, 49889-49893.

Siegel, T., Hekstra, D., Wang, X., Dewell, S. and Cross, G. (2010). Genome-wide analysis of mRNA abundance in two life-cycle stages of Trypanosoma brucei and identification of splicing and polyadenylation sites. Nucleic Acids Res, 38, 4946-4957.

Singh, A., Minia, I., Droll, D., Fadda, A., Clayton, C. and Erben, E. (2014). Trypanosome MKT1 and the RNA-binding protein $\mathrm{ZC} 3 \mathrm{H} 11$ : interactions and potential roles in posttranscriptional regulatory networks. Nucleic Acids Res, 42, 4652-4668. doi: 10.1093/nar/gkt1416.

Tyanova, S., Temu, T., Sinitcyn, P., Carlson, A., Hein, M. Y., Geiger, T., Mann, M. and Cox, J. (2016). The Perseus computational platform for comprehensive analysis of (prote)omics data. Nat Methods, 13, 731-740. doi: 10.1038/nmeth.3901.

Zoltner, M., Krienitz, N., Field, M. C. and Kramer, S. (2018). Comparative proteomics of the two T. brucei PABPs suggests that PABP2 controls bulk mRNA. PLoS Negl Trop Dis, 12, e0006679. doi: 10.1371/journal.pntd.0006679. 


\section{Legends}

\section{Figure 1}

$\mathrm{ZC} 3 \mathrm{H} 28$ is essential and increases the abundance of an attached mRNA

A. Structure of $\mathrm{ZC} 3 \mathrm{H} 28$, drawn to scale. The positions of the zinc finger domain, poly(His) and poly(GIn) sequences are indicated.

B. Effects of tethering lambdaN-tagged $\mathrm{ZC} 3 \mathrm{H} 28$ on a boxB-bearing CAT reporter mRNA. This panel shows expression of the CAT mRNA, with a beta-tubulin control, in the upper three panels; the lower two panels show expression of the lambdaN-tagged protein, which has a myc tag at the $\mathrm{C}$-terminus.

C. Effects of tethering on CAT activity (left) and mRNA (right). Results are expressed relative to cells without any tethered protein construct.

D. Effect of $\mathrm{ZC} 3 \mathrm{H} 28$ depletion on cell numbers; results for two clones are shown.

E. Depletion of TAP-tagged ZC3H28 after RNAi. The stained membrane serves as the control.

A.

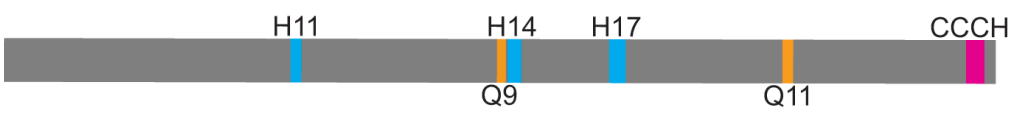

B.
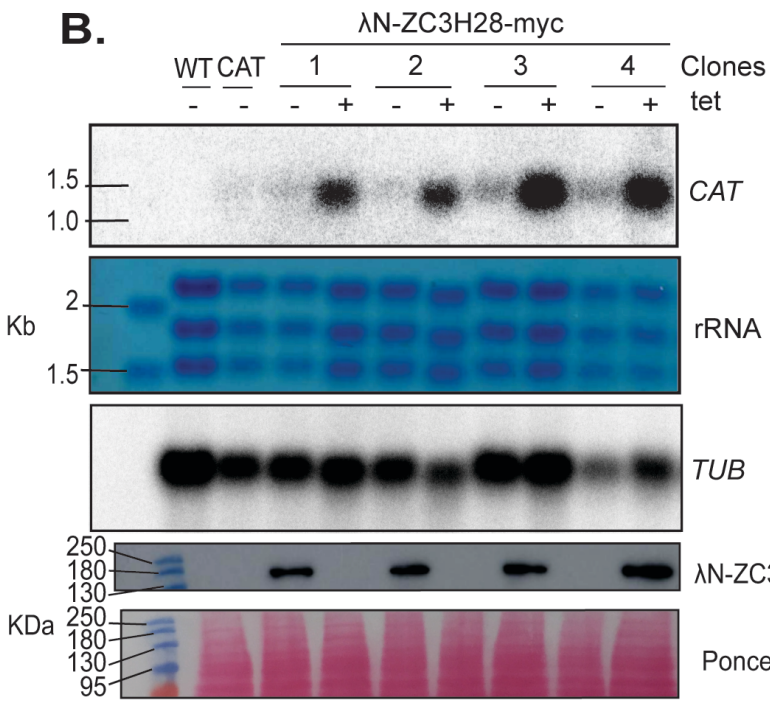

D.

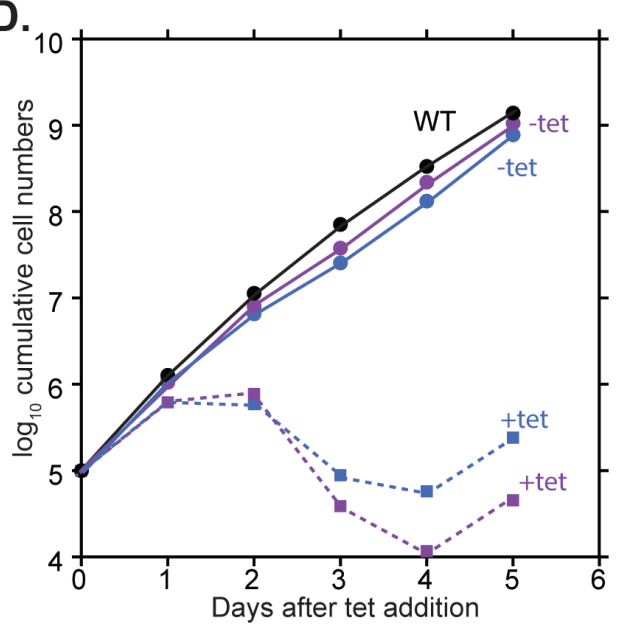

E.
C.

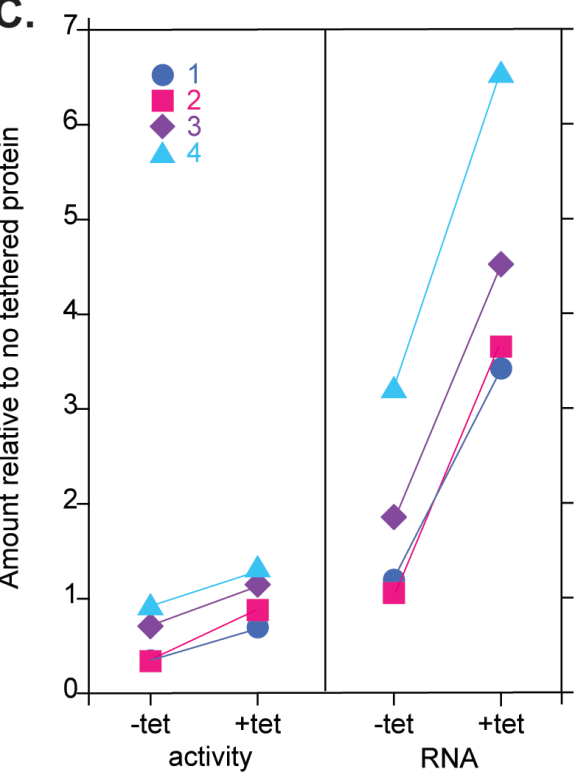

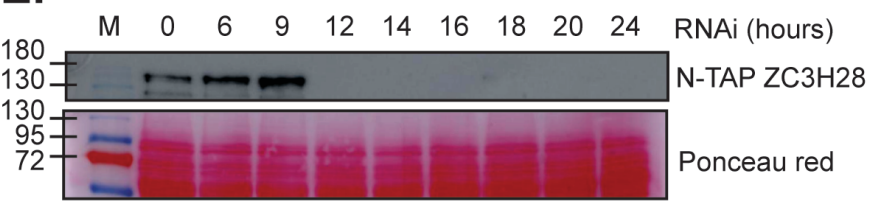




\section{Figure 2.}

Protein interactions of $\mathrm{ZC} 3 \mathrm{H} 28$

A. Interactions of $\mathrm{ZC} 3 \mathrm{H} 28$ in the yeast 2-hybrid assay. S. cerevisiae $\mathrm{AH} 109$ was transformed with combinations of plasmids used as bait ( $\mathrm{pBD}$, DNA binding domain) and prey ( $\mathrm{pAD}$, transcription activating domain). The cells were grown on media lacking adenine, histidine, leucine and tryptophan (SD-WLAH) to test protein interactions and then in media containing adenine and histidine (SD-WL) to check expression of the bait and prey. The interaction between SV40 large T antigen ( $T$ ) and p53 serves as positive control, and encoding lamin $C$ (LamC) and T serves as negative control. PBP1 and XAC fused with the DNA-binding domain both activate when expressed alone (Nascimento et al., 2020), therefore they are used here only as activation domain fusions, which give appropriate negative control results (Nascimento et al., 2020).

B. Volcano plot for mass spectrometry of triplicate purifications of TAP-ZC3H28, compared with TAP-GFP. The Figure was generated using Perseus software (Tyanova et al., 2016).
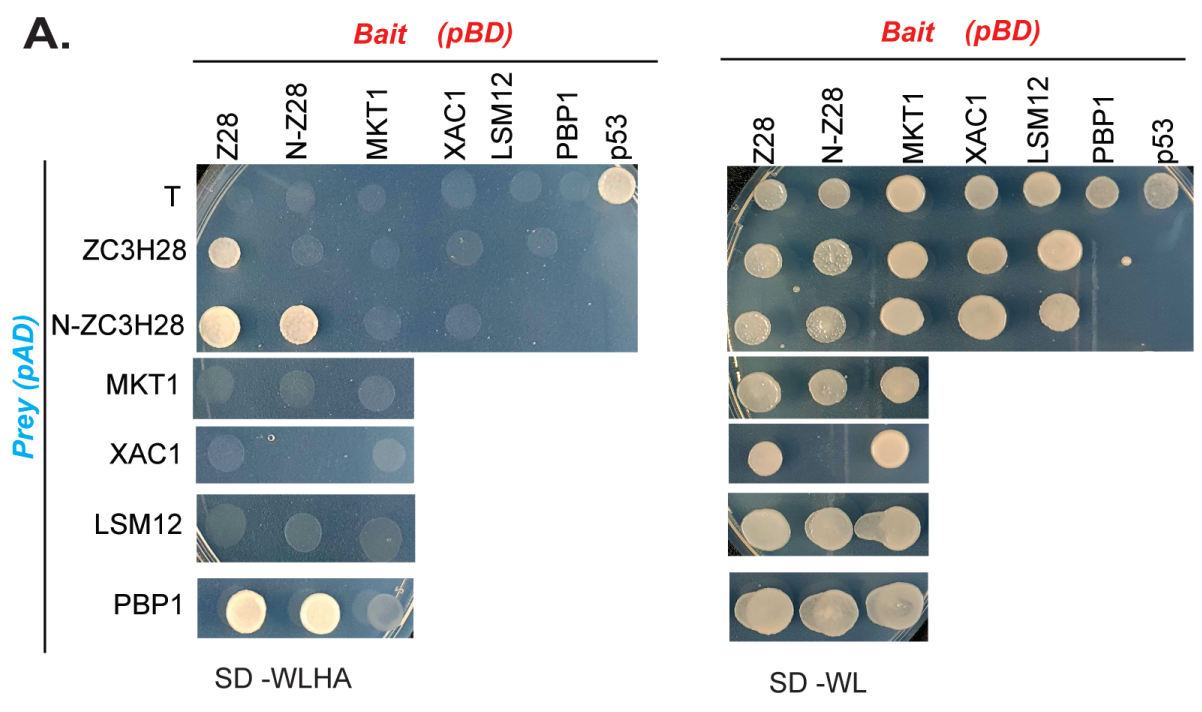

B.

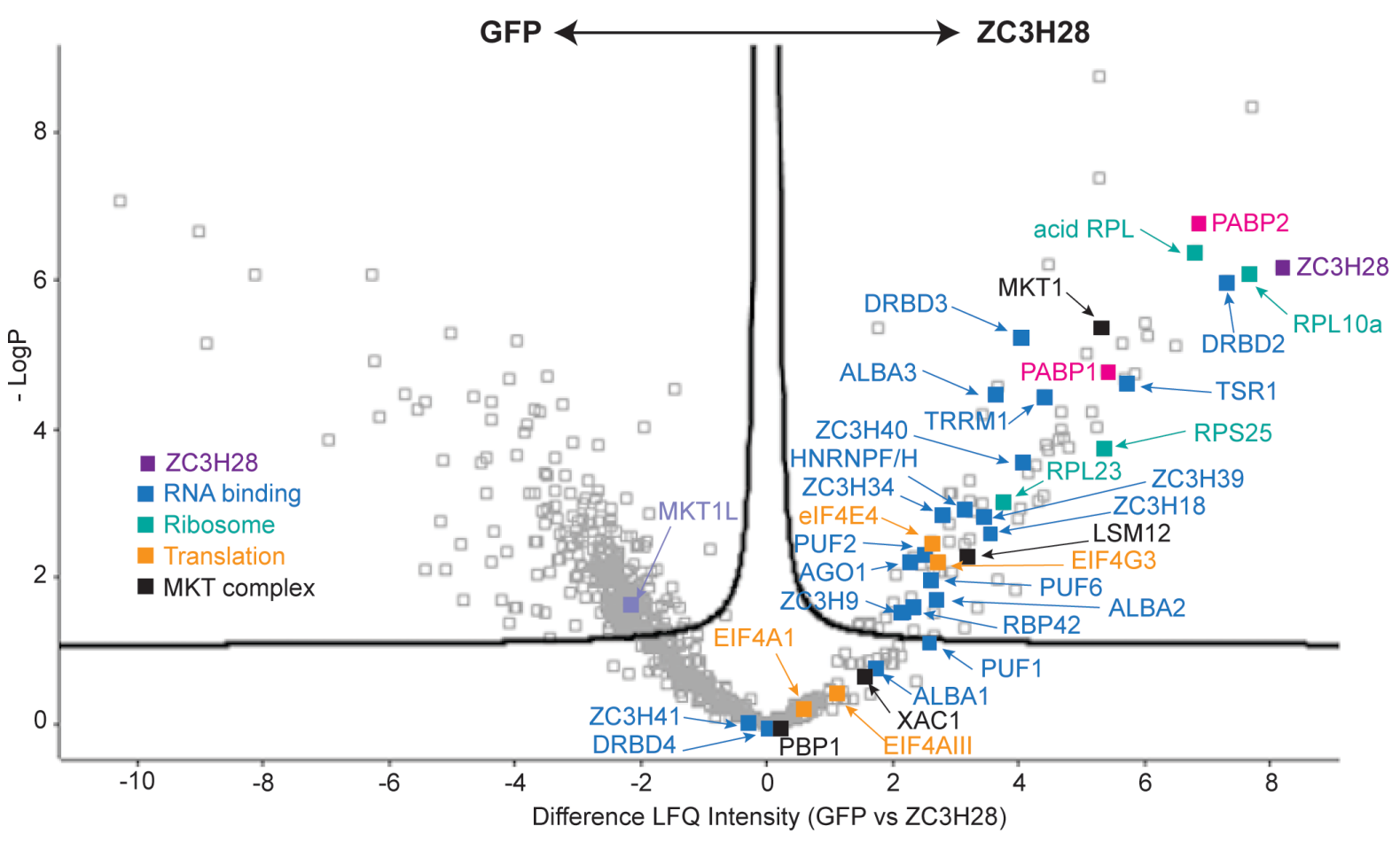




\section{Figure 3.}

Interactions of $\mathrm{ZC} 3 \mathrm{H} 28$ with mRNA.

A. Characteristics of mRNAs that were at least 3-fold enriched with TAP-ZC3H28 relative to the unbound fraction. Results for the whole transcriptome are shown for comparison. All results in this Figure are for the set of unique genes, to avoid over-counting repeated genes.

B. Plot for the whole dataset: enrichment with $\mathrm{ZC} 3 \mathrm{H} 28$ relative to mRNA length.

C. The set of unique genes was placed in functional categories (Supplementary Table S4) and binding to $\mathrm{ZC} 3 \mathrm{H} 28$ was plotted for each category. The dotted line indicates equal distribution in both fractions.

D. Motifs enriched in the 3'-UTRs of ZC3H28-bound mRNAs relative to size-matched controls showing less than 1-fold average enrichment in the bound fraction. 
bioRxiv preprint doi: https://doi.org/10.1101/2021.08.09.455650; this version posted August 9, 2021. The copyright holder for this preprint (which was not certified by peer review) is the author/funder, who has granted bioRxiv a license to display the preprint in perpetuity. It is made available under aCC-BY-NC-ND 4.0 International license.

A.

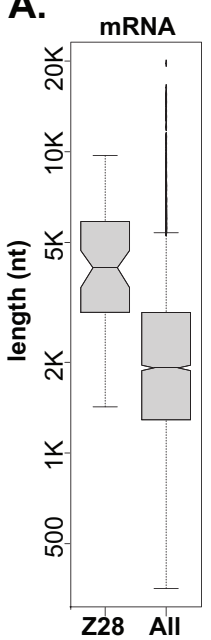

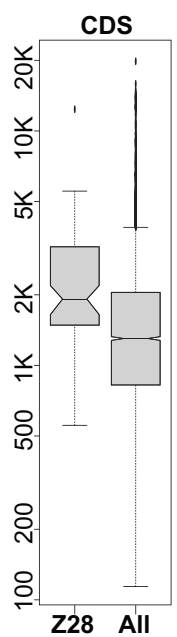
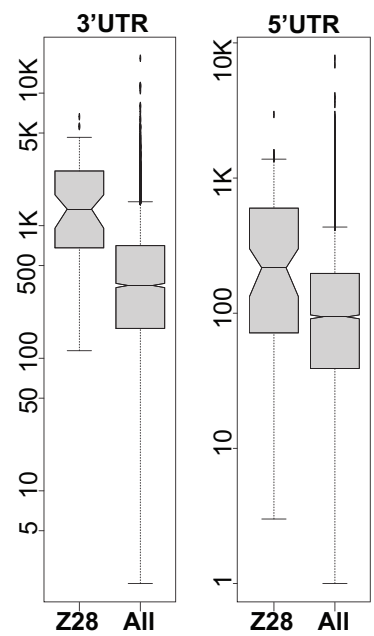

B.

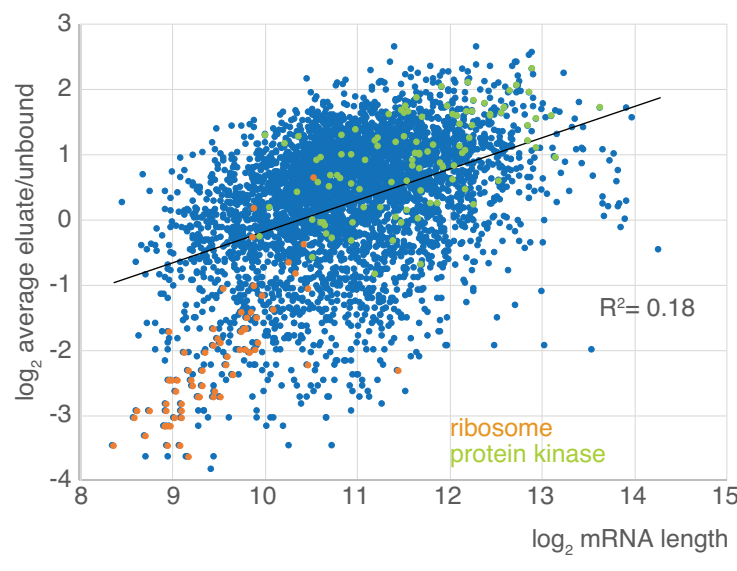

C.

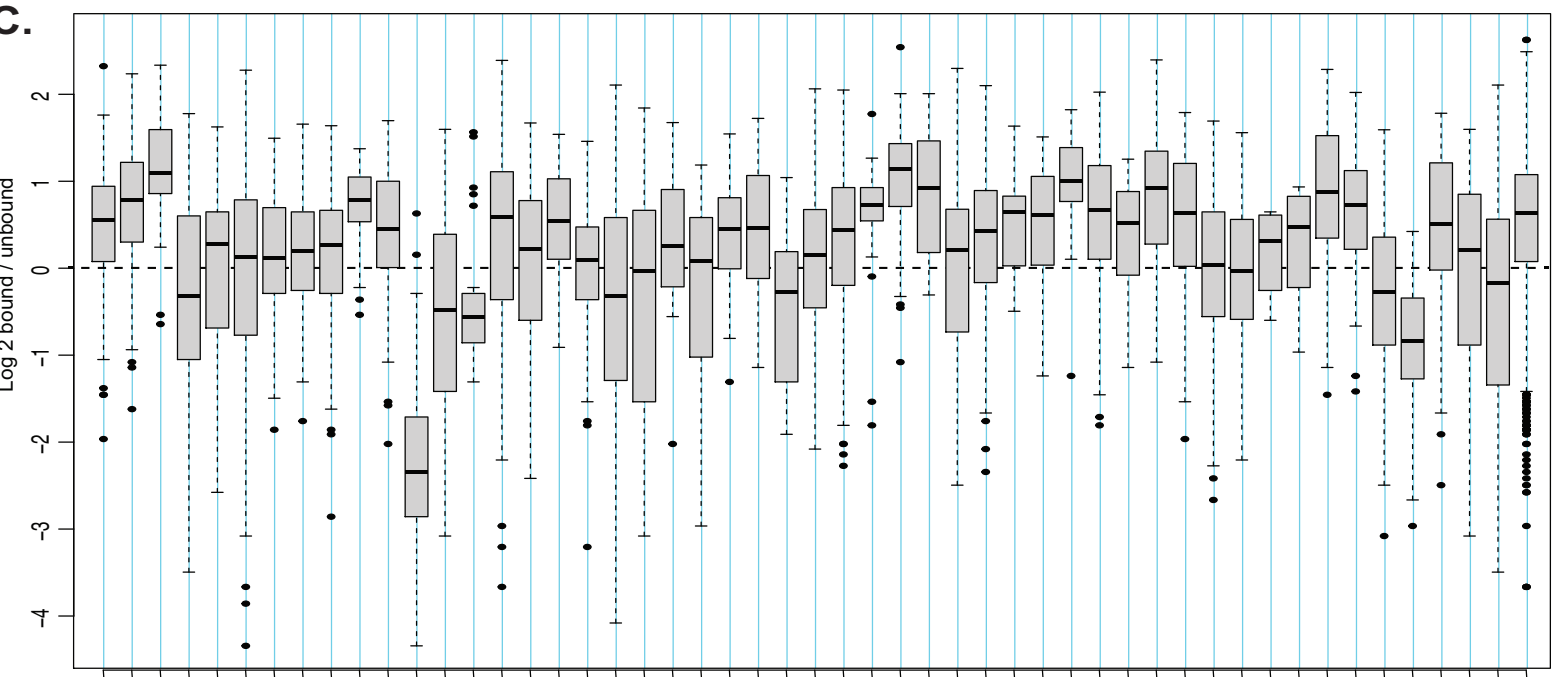

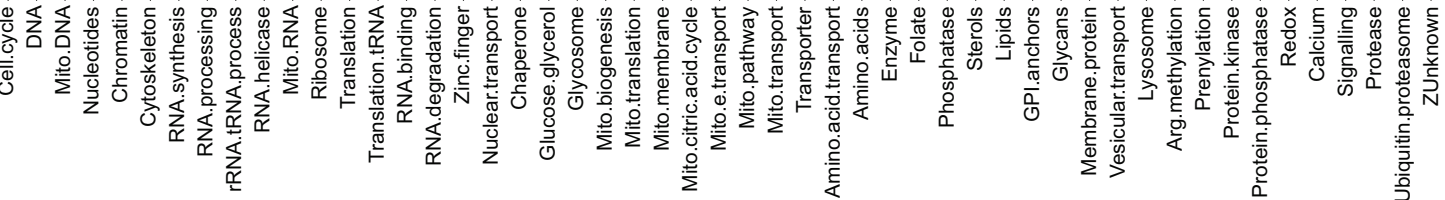

D.

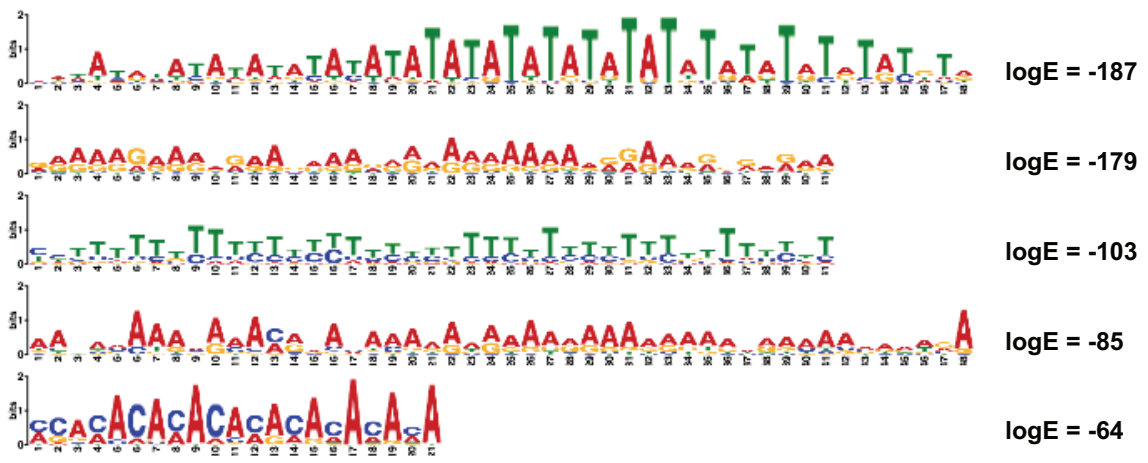




\section{Figure 4.}

Effects of $\mathrm{ZC} 3 \mathrm{H} 28$ depletion on the transcriptome

A. Principal component analysis. Samples without induction are in black and grey; others are colour-coded according to the time with tetracycline. All results in this Figure are for the set of unique genes, to avoid over-counting repeated genes.

$B$. The set of unique genes was placed in functional categories (Supplementary Table S4) and the effects of $\mathrm{ZC} 3 \mathrm{H} 28$ depletion (14h RNAi) were plotted for each category. The green background is the median and 25th percentiles for the total dataset.

C. The effect of RNAi (y-axis) was plotted against the annotated mRNA length (x-axis). Only mRNAs with two annotated untranslated regions were included. Correlation coefficients were calculated in Microsoft Excel.

D. Lack of relationship between the ZC3H28 RNAi effect (y-axis) and ZC3H28 binding (x-axis). 
bioRxiv preprint doi: https://doi.org/10.1101/2021.08.09.455650; this version posted August 9, 2021. The copyright holder for this preprint (which was not certified by peer review) is the author/funder, who has granted bioRxiv a license to display the preprint in perpetuity. It is made available under aCC-BY-NC-ND 4.0 International license.
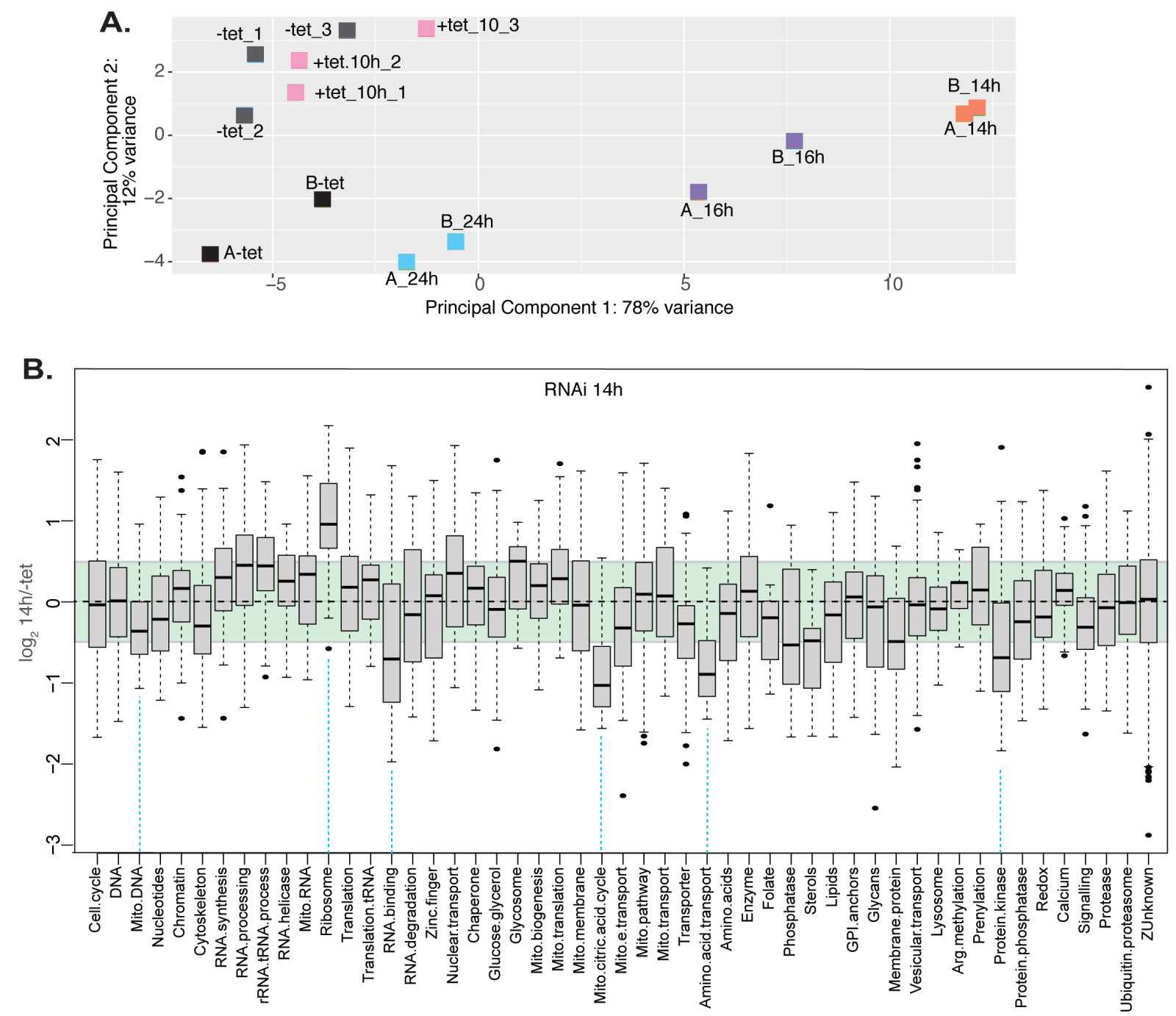

C.

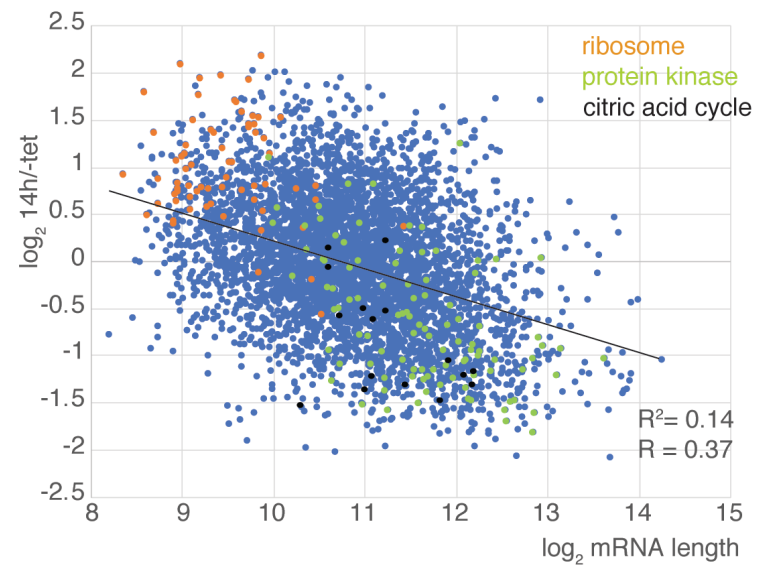

D.

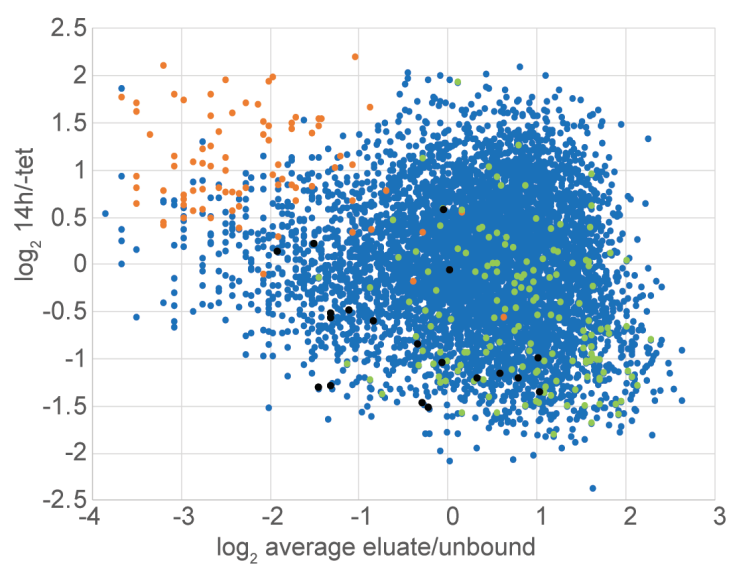




\section{Figure 5.}

$\mathrm{ZC} 3 \mathrm{H} 28$ and translation

A. Binding of mRNAs to $\mathrm{ZC} 3 \mathrm{H} 28$ is on the $\mathrm{x}$-axis, and the ribosome density on the y-axis.

$B$. Binding of mRNAs to $\mathrm{ZC} 3 \mathrm{H} 28$ is on the $\mathrm{x}$-axis, and enrichment in procyclic-form starvation granules (Fritz et al., 2015) is on the y-axis.
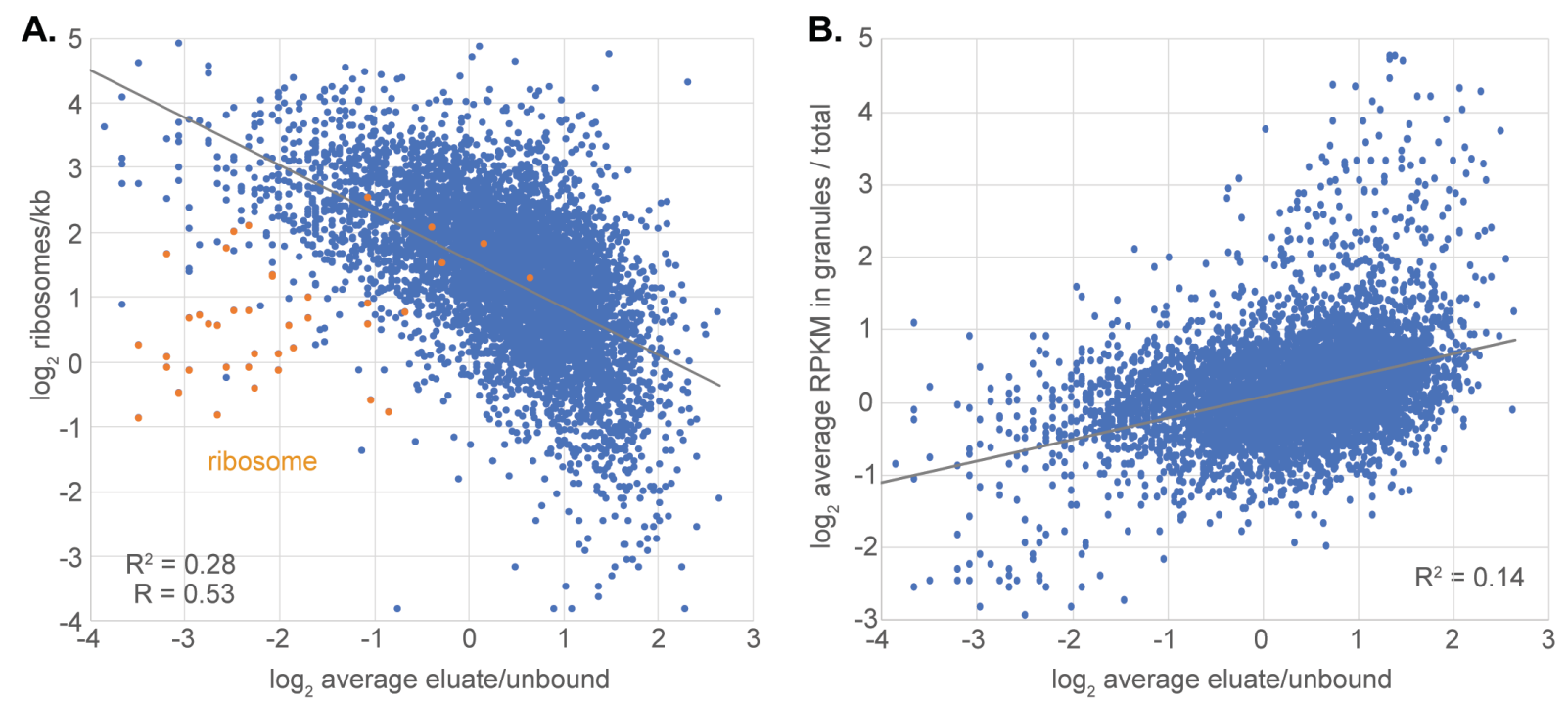

\section{Supplements}

\section{Supplementary Figure S1}

Alignment of protein sequences for selected kinetoplastids and Bodo saltans.

The alignment was done using Phyre2 with default settings. The tree at the top shows the source organisms. 
bioRxiv preprint doi: https://doi.org/10.1101/2021.08.09.455650; this version posted August $9,2021$. The copyright holder for this preprint (which was not certified by peer review) is the author/funder, who has granted bioRxiv a license to display the preprint in perpetuity. It is made available under aCC-BY-NC-ND 4.0 International license.

\section{Supplementary Figure S2}

Growth of trypanosomes used for RNAi transcriptomes.

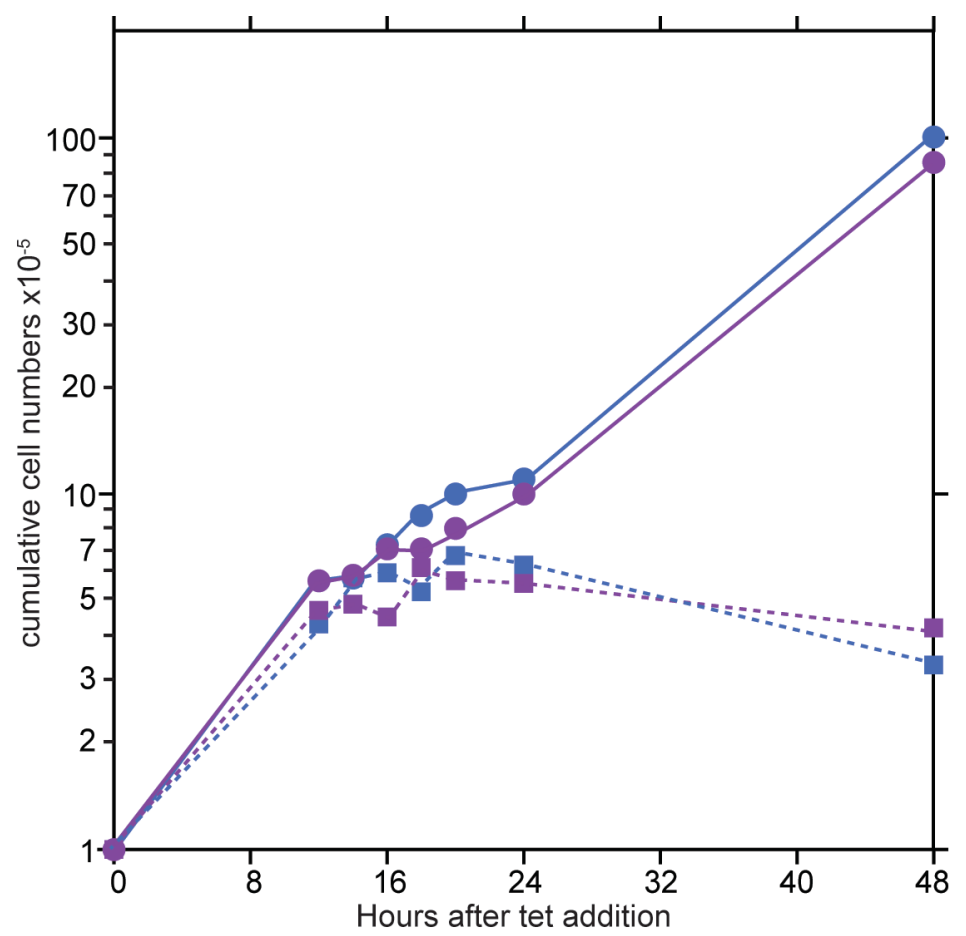


bioRxiv preprint doi: https://doi.org/10.1101/2021.08.09.455650; this version posted August 9, 2021. The copyright holder for this preprint (which was not certified by peer review) is the author/funder, who has granted bioRxiv a license to display the preprint in perpetuity. It is made available under aCC-BY-NC-ND 4.0 International license.

\section{Supplementary Figure S3}

Effect of RNAi and cell density on mRNA levels and protein synthesis.

A. Effect of ZC3H28 RNAi on total mRNA, detected with a spliced leader probe. There is some cross-hybridization with the rRNA but the signal above and below gives an indication of overall mRNA levels..

B. Effect of cell density and ZC3H28 RNAi on protein translation in Clone 1. The stained membrane is on the right and the 35S-Met+Cys incorporation on the right. Quantitation (using the protein stain as the control) revealed that the signal from radioactive incorporation was approximately halved at cell densities over $10^{6} / \mathrm{ml}$.

C. As for (B) but using clone 2. Quantitation was not possible because the protein stain was not even across the gel.

\section{A. Effect of RNAi on total mRNA}
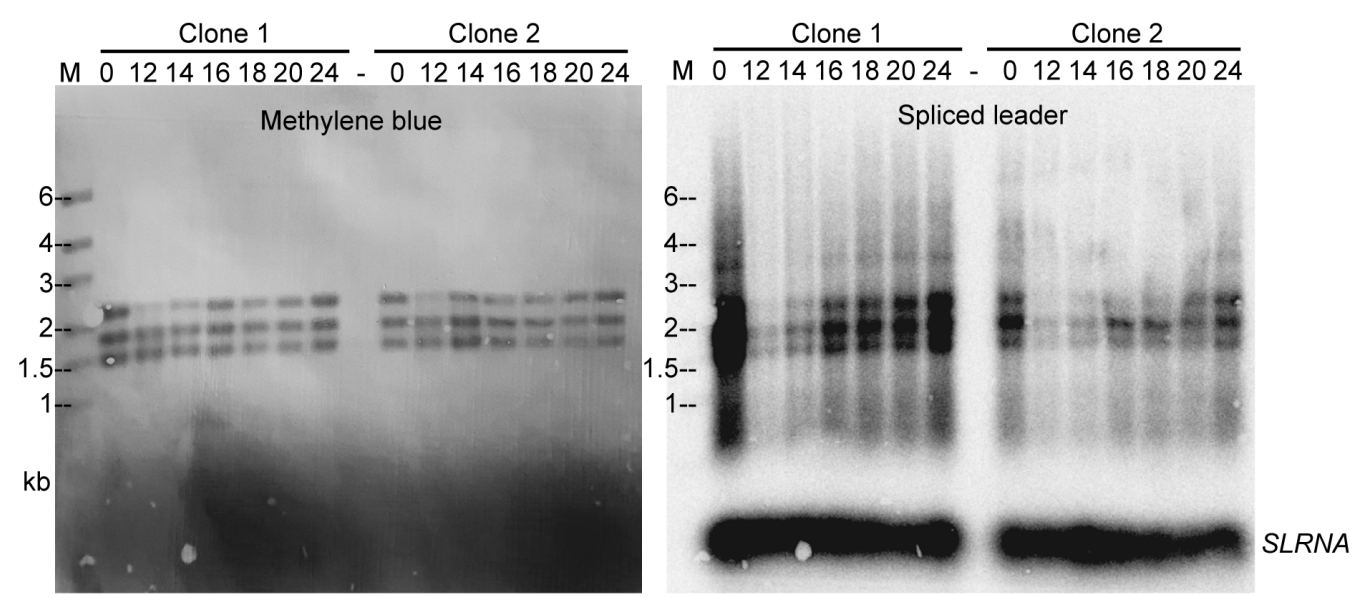

B. Effect of cell density and RNAi on translation
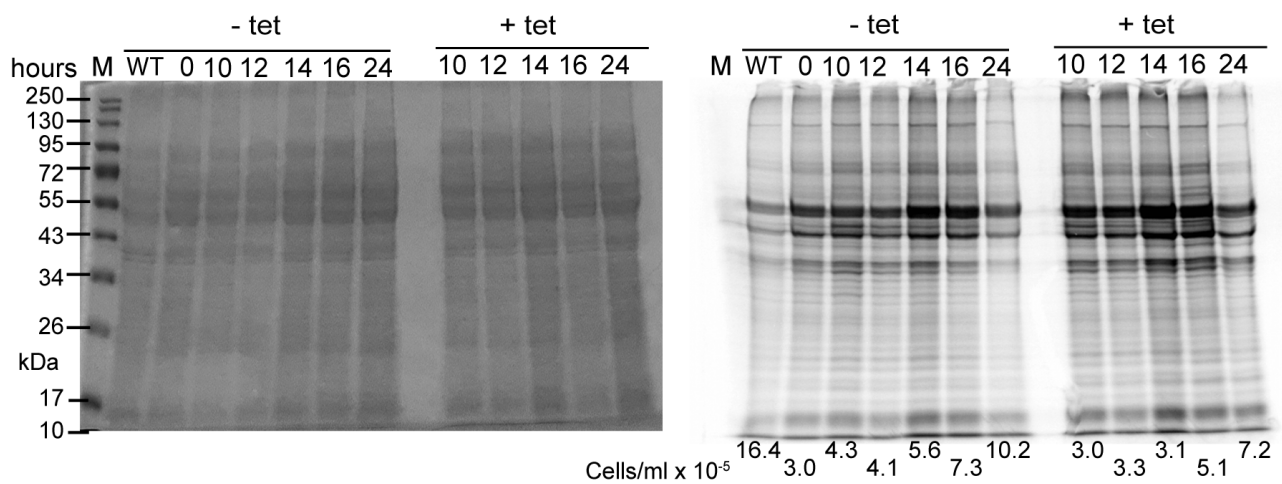

Clone 1

C. Effect of cell density and RNAi on translation

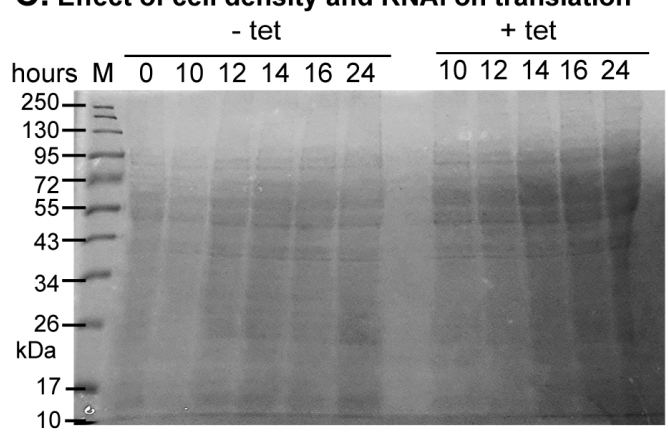

Cells $/ \mathrm{ml} \times 10^{-5}$
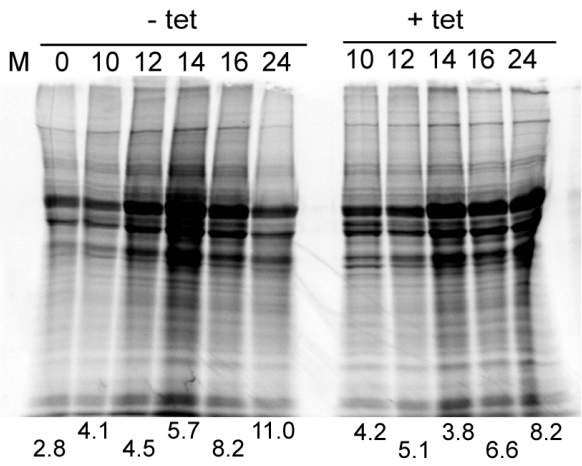

Clone 2 


\section{Supplementary Table S1}

Complete mass spectrometry results. Details are on the first sheet.

\section{Supplementary Table $\mathbf{S 2}$}

RNAs associated with $\mathrm{ZC} 3 \mathrm{H} 28$. Details are on the first sheet.

\section{Supplementary Table S3}

Effect of $\mathrm{ZC} 3 \mathrm{H} 28$ on the transcriptome: results for all genes. Details are on the first sheet.

\section{Supplementary Table S4}

Effect of $\mathrm{ZC} 3 \mathrm{H} 28$ on the transcriptome: results for the unique gene set. Details are on the first sheet.

\section{Supplementary Table S5}

List of plasmids and oligonucleotides 